УДК 94(4)

UDC

DOI: $10.17223 / 18572685 / 64 / 3$

\title{
The life and work of Stefan Pankovych, the Bishop of the Greek Catholic Eparchy of Mukachevo*
}

\author{
Ferenc Molnár \\ Ferenc Rákóczi II Transcarpathian Hungarian College \\ of Higher Education \\ 6 Kossuth Square, Berehove, 90202, Ukraine \\ E-mail:molnarkmf@gmail.com
}

\section{Abstract}

When Bishop Stefan Pankovych (1866-1874), who succeeded Vasyl Popovych (died in 1864) was inaugurated, he was almost unknown to the Rusin clergy of the Greek Catholic Eparchy of Mukachevo. The new bishop maintained good relations with members of the Hungarian political elite and actively supported the policy of the Hungarian government. This was manifested on several levels. He promoted to high ecclesiastical positions those who did not support Adolf Dobriansky, a Russophile considered the most significant Rusin leader. Following the Austro-Hungarian Compromise of 1867, Rusin leaders had the opportunity to hold various offices, mainly with the trust of the Hungarian government and the Bishop of Mukachevo. In 1871, Bishop Stefan Pankovych and his followers removed Adolf Dobriansky and Ivan Rakovsky from the leadership in St. Basil the Great Society, which led to a gradual decline of the Russophile trend in the Rusin movement. The Great Russian camp supporters also confronted Stefan Pankovych because of the attempt to introduce the Gregorian calendar and the Latin alphabet in the Mukachevo Diocese. Even more moderate clergy were divided on such issues, because these concepts were important for Rusin identity. However, Stefan Pankovich's unexpected death on August 29,1874,temporarily froze debates in the Rusin movement.

Keywords: Stefan Pankovych, Greek Catholic Diocese of Mukachevo, Rusins, Uzhhorod, Russophiles, Adolf Dobriansky.

\footnotetext{
*The study was supported by the ÚNKP-20-4 New National Excellence Program of the Ministry for Innovation and Technology from the Source of the National Research, Development and Innovation Fund (Hungary).
} 


\section{Жизнь и деятельность мукачевского \\ греко-католического епископа \\ Стефана Панковича}

\section{Ференц Молнар}

Закарпатский венгерский институт им. Ференца Ракоци II Украина, 90202, г. Берегове, пл. Кошута 6

E-mail: molnarkmf@gmail.com

\section{Авторское резюме}

Стефан Панкович, избранный епископом после смерти Василия Поповича в 1864 г., был малоизвестной личностью в среде русинского духовенства Мукачевской греко-католической епархии. Новый епископ имел хорошие контакты с венгерской политической элитой и был сторонником политики венгерского правительства. Это проявилось в нескольких вещах. После австро-венгерского компромисса 1867 г. получить руководящие должности сумели преимущественно те русинские деятели, которые пользовались доверием и венгерского правительства, и мукачевского епископа. Стефан Панкович отбирал на высокие церковные должности людей, не поддерживавших русофильских взглядов самого известного в то время русинского лидера Адольфа Добрянского. В 1871 г. епископ и его сторонники отстранили А. Добрянского и И. Раковского от руководства «Обществом святого Василия Великого», что привело к постепенному упадку русофильского направления в русинском движении. Последователи Добрянского выступили против руководителя епархии и из-за его попытки внедрить в Мукачевской епархии григорианский календарь и латинский алфавит. В таких вопросах разделилось мнение даже более умеренного духовенства, ведь эти понятия были важными элементами русинской идентичности. Но неожиданная смерть Стефан Панковича 29 августа 1874 г. на определенное время заморозила дискуссии в русинском движении.

Ключевые слова: Стефан Панкович, Мукачевская греко-католическая епархия, русины, Ужгород, русофилы,Адольф Добрянский.

The so-called October Diploma issued in the autumn of 1860 proclaimed a return to constitutional principles in the Habsburg Empire. It is in this spirit that parliamentary elections were held in Hungary which had a great impact on the Rusins of the country, most of whom lived in the territory of Greek Catholic Eparchy of Mukachevo [21:121-122; 23: 160]. The current bishop of the diocese, who resided in Uzhhorod 
was considered to be the number one leader of the Rusins [81: 6, 21]. Vasyl Popovych, Bishop of Mukachevo, who had also been the Emperor Franz Joseph's privy councillor since 1863, tried to balance between Vienna and the Hungarian political elite [73: 64]. During 1861, many Rusin priests and intellectuals formulated their linguistic and national demands. Compared to other Rusin leaders, the councillor of Hungary's Lieutenancy Council and later court counselor, Adolf Dobriansky's programme was the most radical with the suggestion of the federal transformation of Hungary and the establishment of an autonomous Rusin district [16: 172-173; 21: 122; 51: 488; 64: 33]. Bishop Vasyl Popovych wanted to avoid a confrontation with the Hungarian leaders seeking to establish the Austro-Hungarian Compromise, so he did not support the Russophiles led by A. Dobriansky. The bishop was unable to become an active participant in the turmoil of events because of his serious illness and his death in the autumn of 1864 [73: 64]. The solution of the increased problems remained with Stefan Pankovych, who became the next bishop of Mukachevo.

Although the significance of the Russophile movement in northeastern Hungary during the 1860-1870s has been discussed in the literature, the biography and the activities of pro-Hungarian Bishop Stefan Pankovych can be mentioned among the less researched issues. Some aspects of his episcopate have been examined in the publications of D. Danyliuk [5], M.Yu. Kashka [16; 17], R.I. Mayor [21; 22; 23], M. Mayer [64], V. Padyak [26; 27], A.B. Pekar [72] and etc. Russophile contemporaries such as I. Silvay [24; 25],V. Terletsky [36] and I. Rakovsky [14] also took pen in hand to record the events of Stefan Pankovych's episcopate. Contemporaries and historians are divided on the bishop's historical evaluation. According to some opinions, Stefan Pankovych was "a renegade", "a magyarone" or "an assimilator" [23: 163; 26: 11; 57: 276; 80: 216], and his followers were called "the Magyarones", "the members of the bishop's party" "the opportunists","the utilitarians","the moderates" or "the renegades" [23:163; 26:11; 28:395]. From the Hungarian point of view, he was a "Hungarian patriot" or a "true reformer" [72: 190; 73: 65; 88].

The main purpose of this study is to provide insight into Stefan Pankovych's life and work. It also provides supplements for understanding the internal conflicts of the Rusin movement.

Stefan Pankovych was born on October 27 or 29, 1821, in Velejte (today Vel'aty, Slovakia) belonging to Count Andrássy's estate in Zemplyn (Zemplén) County. His father was the Greek Catholic priest of the village. Stefan completed the grammar school classes in Sátoraljaújhely (today Hungary) and Szatmárnémeti (today Satu Mare, Romania), and theology 
at the seminary in Uzhhorod. He was then accepted as a home teacher by Baron Ágoston Vécsey's widow [69: 73; 72: 190; 73: 65; 74: 372].

In 1850, Pankovych was appointed a teacher of mining law and statistics at the Academy of Košice. On August 27, 1851, Bishop Vasyl Popovych ordained him a priest and appointed him to his father's parish. The ambitious young priest wanted to work as a diocesan clerk or secretary. After his expectations for his church career were not met, he decided to break up with the priesthood. Thus he joined the Nákó family for about 14 years. As a home teacher of Count Kálmán Nákó, he had the opportunity to travel to Europe, Egypt and West Africa [24: 55-57; 68; 69: 73; 72: 190; 74: 372]. He fit well into the circles of the Hungarian aristocracy [18: 96]. As Ivan Silvay, a writer in the Great Russian language, put it:"Despite his tutor appearance, just his long clerical robe and cleanshaven face distinguished him from the members of the high society" [64: 139].

Thanks to his relations, his office career accelerated in the 1860s. In 1865, he was awarded the title of Archimandrite of Hrushevo Monastery, and at the same time he was appointed study lecturer at the Hungarian's Lieutenancy Council. Through his appointment, he gained influence in the management of church affairs [40: 96; 69: 74].

In 1865, the political life of Hungary took a turn. On June 26, Franz Joseph I appointed György Mailáth Hungarian Chancellor, and by December, the Emperor reconvened the Hungarian parliament, which in 1867 approved the Austro-Hungarian Compromise. As a result, the Hungarian Kingdom gained extensive self-government in the Habsburg Empire, and the Hungarian nobility regained its leading role within the country [83: 739-748].

For about two years after the death of Bishop Vasyl Popovych on October 19, 1864, Vicar Antal Csopey administered the Eparchy of Mukachevo. In the years before the Austro-Hungarian Compromise, the conservative Hungarian leaders led by Chancellor Mailáth wanted to see a person at the head of the eparchy who was accepted by both Vienna and Hungarian political circles [40: 96]. This is how the young and talented Stefan Pankovych, who had close ties to the Hungarian nobility, was chosen. Franz Joseph I appointed him Bishop of Mukachevo on September 14,1866. Papal confirmation took place on February 22, 1867 [40: 96; 72: 190; 73: 65]. Stefan Pankovych's episcopal appointment was also due to the fact that at their meeting in Hajdúdorog on May 6, 1866, Hungarian-speaking Greek Catholics asked the Emperor, János Scitovszky, the Archbishop of Esztergom, Chancellor Mailáth and the Hungarian government to appoint "a Hungarian patriot" as Bishop of Mukachevo [73: 65; 92: 82-84]. 
Prior to the official inauguration of the new bishop, the Consistory of the Eparchy of Mukachevo greeted Count Gyula Andrássy on the occasion of his appointment as Prime Minister of Hungary [6]. In a letter published in the form of a press release, the prelacy believed in the Austro-Hungarian Compromise and the Hungarian government. The Consistory hoped that the Andrássy cabinet would provide support to combat the deep poverty in the Eparchy of Mukachevo and help find a solution to the "complications" of the nationality question that would be satisfactory to all parties [86].

Stefan Pankovych was consecrated on May 5, in Prešov [40: 90; 72: 190]. After that, all that was left - his official inaguration. On May 15, 1867, he marched to his bishopric seat in Uzhhorod, referred to by the pro-government "Pesti Naplo" [Pest Diary] as the "Mecca of Greek Catholics", where crowds of spectators greeted him in Hungarian and Rusin. According to the journal, the public opinion had an expectation of the new bishop that the interests of the Andrássy government should be firmly reflected in his political role [87]. Things started to move in that direction. The solemn inauguration of the bishop was held on May 16. He gave his inaugural speech, but in addition to Hungarian, it was also distributed in Rusin [32], Latin and German translations. In his address, Stefan Pankovych emphasized his loyalty to the Hungarian homeland and the king [87]. The new bishop had a frequently uttered slogan:"God, King, Home!" [24: 55; 73: 65].

After his inauguration, Stefan Pankovych became the head of an eparchy of nearly 400,000 people, whose jurisdiction extended to Zemplyn (Zemplén), Uzh (Ung), Bereg, Ugocha (Ugocsa), Maramorosh (Máramaros), Szabolcs and Sotmar (Szatmár) Counties. Most of the believers were Rusins, but in addition to them, the number of Hungarians and Romanians was also significant. The eparchy consisted of 376 parishes [82]. By consecration, as the other Mukachevo bishops, Stefan Pankovych received the title of Archimandrite of the Monastery of Sts. Peter and Paul in Tapolca (today Miskolctapolca, Hungary) [32: 1; 72: 60, 223].

In October 1867, an anonymous correspondent in Pro-Hungarian orientation of "Pesti Naplo" noted with satisfaction that Stefan Pankovych had taken over the management of the Eparchy of Mukachevo as a "true reformer". In two months, the bishop submitted a nomination for the appointment of five persons as archdeacon to Franz Joseph I, who had meanwhile been crowned king of Hungary. The journal praised the bishop for helping to appoint "patriotic" clergy who could support the elite of the counties of north-eastern Hungary [88]. The bishop needed to surround himself with people he believed to be trustworthy, as he was almost unknown to the priesthood before his appointment as bishop. 
The main positions of the eparchy at that time were still held by those who owed their appointment to Bishop Vasyl Popovych [67: 450].

The pro-Hungarian bishop started his work enthusiastically, as evidenced by the fact that, after his inauguration, he made canonical visits to several archdeaconates. On these occasions, on the one hand, he had the opportunity to use his personal persuasive power and to explain the new political situation created by the Compromise to his clergy and the mostly illiterate Rusin peasants. On the other hand, he could obtain information about the urgent problems of the local parishes (lack of financial resources, schools, textbooks, etc.), for the solution of which he often sought the help of the Hungarian Ministry of Religion and Culture. Stefan Pankovych visited Mukachevo during 1867 [88]. The following September his next stations were the Hungarian-speaking parishes of Hajdú District and of Maramorosh County, where he distributed hundreds of Hungarian and Rusin reading books, Bibles and catechisms [7].

During his visit to Hajdúdorog, the bishop openly informed the locals that he supported the establishment of an independent Hungarianspeaking eparchy. Stefan Pankovych "in the festive moments $<. . .>$ even stated that he considered it the most beautiful task of his life to be the first Hungarian Greek Catholic bishop" [91: 40]. The main goal of the supporters of the so-called Hajdúdorog Movement was to create an independent diocese from the Hungarian-language parishes of the Eparchy of Mukachevo. At the same time, they demanded the permission to use the Hungarian language in liturgy that was a violation of canon law [3: 18-26; 40: 101; 56: 57; 63; 72: 88]. In light of this, the ruler's decision to establish the Hajdúdorog Vicariate under the authority of Bishop Stefan Pankovych on September 17, 1873, instead of an independent diocese, was very disappointing for the Hungarian believers. However, the vicariate with 33 parishes became the basis of the Eparchy of Hajdúdorog, founded in 1912 [59: 138; 72: 92-94; 73: 91, 109].

Stefan Pankovych visited Maramorosh County on September 6, 1868, where had not been a bishop of Mukachevo for 91 years [70]. The situation here was quite complicated. Among the Greek Catholic believers of the county and its capital, Máramarossziget (today Sighetu Marmației/Sighet, Romania), which also serves as a vicariate centre, we find both Rusins and Romanians. The priest of the city, Vicar Peter Anderko of Romanian origin, supported the initiative to separate the parish of Sighet from the Eparchy of Mukachevo and to attach it to the Romanian-speaking Gherla (Szamosújvár) Eparchy. By joining the Romanian Greek Catholic Church, the believers of Maramorosh would have come under the direct rule of Rome. This plan would have eliminated their dependence on the leader of the Hungarian Catholic 
Church, the Archbishop of Esztergom. Not surprisingly, the Hungarian government protested against the idea. On August 29,1865, Hungary's Lieutenancy Council declared Sighet as a Rusin parish and left it under the jurisdiction of the Eparchy of Mukachevo [10; 46: 32-33; 72: 71]. As early as 1867, after the inauguration of Stefan Pankovych as bishop, he appointed his nephew, loann (Ivan) Pastelii Kovach Archdeacon of Maramorosh [72: 190].

Even during his visit in 1868, Stefan Pankovych was unable to dissuade Romanian believers from their original plan for separation. In a confidential letter dated 24 May, 1869, the bishop instructed the temporary priest of Sighet, Mihály Suba, to inform him by telegram as soon as possible in the event of the death of his superior, the elderly and ailing Anderko. The funeral of the vicar can only be performed by a priest under the jurisdiction of the Eparchy of Mukachevo [12]. On June 2, Anderko passed away [45]. The newspaper "Máramaros" wrote about him that "with his death, the last link that connected the Romanians of Maramorosh to the Eparchy of Mukachevo was broken" [90]. Subsequently, local Romanian believers sought permission from Bishop Stefan Pankovych and then János Simor, Archbishop of Esztergom to join the Romanian-speaking Gherla Eparchy in order to preserve their mother tongue and nationality from the influence of the Rusin Church [9; 11]. (Similar reasons were raised by adherents of the Hajdúdorog Movement.) Pankovych, however, found the secession unacceptable. His view was shared by Franz Joseph. After the death of Anderko, Bishop Stefan Pankovych appointed Ioann Pastelii Kovach as vicar of Maramorosh [72: 190; 73: 66]. The new vicar, who also served as the parliamentary representative of Huszt (today Khust, Ukraine) in the colours of the Hungarian ruling party between 1869 and 1872, brought an intermediate solution. On July 8,1871, Vicar loann Pastelii Kovach divided the Rusin and Romanian parishes of Sighet, leaving them under the jurisdiction of Uzhhorod [40: 103-104; 46: 33].

Thanks to his excellent relations with the Hungarian government, the bishop of Mukachevo obtained considerable financial support for his eparchy. According to the newly-appointed Minister Baron József Eötvös, Stefan Pankovych also asked for "the last garas (i. e. coins)" from the coffers of the Religious Fund managed by the Ministry of Religion and Culture [77]. The received amount exceeded 100 thousand forints. From this, the bishop completed the construction of the episcopal palace in Uzhhorod, remodelled the orphanage of the young boy priests and purchased a building for the ladies' institute. At his intervention, the Religious Fund raised the salaries of the canons. It has provided significant aid to many parishes [73: 65]. At bishop's request, the ruler 
and his wife, Elizabeth, presented the cathedral of Uzhhorod with precious gold-embroidered silk mass robes at Christmas 1870 [8].

Stefan Pankovych's provisions also affected the life of the theological seminary in Uzhhorod. In 1870, he ordered the presentation of domestic law and statistics so that priests could provide legal advice to their followers if necessary [49: 197-198]. However, he did not support Rusin language education. Until the middle of the $19^{\text {th }}$ century, the seminary in Uzhhorod was a bastion of Rusin identity and culture, reproducing the elite. If a Rusin young person who wanted to join the elite of his people had to enrol in the seminary in Uzhhorod [56: 17-20; 59: 136-137; 80: 216]. Following the Compromise of 1867, career building led to identification with Hungarian culture. During the service of Bishop Stefan Pankovych, with the help of the educational institution, the first generation of Hungarian-minded Greek Catholics was formed, calling themselves "Hungarian Greek Catholics" or "Uhro-Rusins" [22: 331; 40: 97; 80: 215-216].

An article in the opposition newspaper, "A Hon" [Homeland] claimed that the seminary in Uzhhorod forced the greatest rigor and the most conservative Catholic (Ultramontane) views on the youth studying there [43]. At the request of the Hungarian government, Stefan Pankovych repatriated four seminarians of the Eparchy of Mukachevo studying at the Barbareum of Vienna in 1873, who were able to continue their studies in Pest or Esztergom, Hungary. The bishop wanted to prevent Rusin students from building "Pan-Slavic" relations with young people from the Slavic regions of the Austro-Hungarian Monarchy [3: 17; 40: 100; 56: 57]. A newspaper article in 1874, however, praised the fact that the seminarians had founded the Hungarian Literary Self-Education Circle [60]. This year, the institution had 79 Rusin and only four Romanian students [41].

However, not everyone wanted to follow Stefan Pankovych's policy of supporting assimilation. A. Dobriansky became the first president of the St. Basil the Great Society, which aimed to promote the education of Greek Catholics living in the eparchies of Mukachevo and Prešov [5:166, $170 ; 39: 2,16 ; 56: 53-54 ; 64: 15-27]$. The main initiators of the Rusin society were the Greek Catholic bishops, losyf Gaganets of Prešov and Vasyl Popovych of Mukachevo. It began to function on 1 October, 1866 [25:80;29:70; 36:30; 93:65]. At the beginning the society numbered nearly 350 members. It included both ecclesiastical and secular representatives of the Rusins [17: 19; 28: 395; 29: 71; 34: 37]. Thanks to A. Dobriansky's activities, a significant portion of the association's membership followed the Russophile line, several of whom also sympathized with Orthodoxy. Its presidency was dominated by priests who graduated 
from Greek Catholic seminary or theology [29: 71; 56: 207-212; 58: 444-445]. These include Vice President Ivan Rakovsky, who from 1859 served as parish priest of Iza (today Ukraine) in Maramorosh [75: 411]. On the initiative of I. Rakovsky, an expert in newspaper editing, the first Rusin newspaper in north-eastern Hungary, "Svit” [Light], was published in Uzhhorod on July 13, 1867 [28: 395; 40: 97; 50: 24-26].

I. Rakovsky designated Great Russian as the language of the paper, which he considered a weapon against Pankovych-backed assimilation [2:140; 17: 19; 24: 64-65; 80: 214]. "Svit" predominantly published articles expressing sharp criticism of the bishop's denationalization policy [56: 56; 80: 216]. For the Rusin clergy, the Russian language proved incomprehensible and unpopular [15,20,37]. Not surprisingly, the readers of "Svit" dropped from 400 to 200 in half a year [2:140; 24: 79-81; 50: 25 -26]. However, On December 16,1869, Bishop losyf Gaganets of Prešov imposed the support and dissemination of the "Svit" as a national duty of the Greek Catholic clergy and teachers [33: 85; 50: 25-26].

Bishop Stefan Pankovych, who acted vigorously in all areas, often confronted the Russophile leadership of the St. Basil the Great Society [52]. On the last day of September, 1869, a renewal meeting of the association was held in Uzhhorod. The bishop criticized Dobriansky's activities on a number of points before the general meeting. Stefan Pankovych complained that the society neglected the publication of folk education and books in Hungarian, although these activities were also among the original objectives of it. As a result, he envisaged ending his patronage support. However, the bishop failed to convince the general assembly. The membership re-elected A. Dobriansky as president by 43 votes against bishop's candidate (Adviser to the Interior Minister, Antal Ruby), who received only 24 votes [30: 2; 89].

The contradictions between the Russophile and the pro-Hungarian Rusin tendencies sharpened during the first Hungarian Congress of Catholic Autonomy (1870-1871) [34:38; 40: 98]. At that time,A. Dobriansky, as a secular envoy, took the position that the self-determination of Greek Catholics within the Hungarian Catholic Church should be supported. In his view, Greek Catholics should convene a special congress. For historical reasons, he sought to substantiate his claim that the right to elect a bishop should belong to the Greek Catholic clergy, not the ruler [1; 3: 22; 72: 90]. Bishop Stefan Pankovych and his followers did not support A. Dobriansky's ideas in the field of ecclesiastical autonomy, as they believed that these demands would jeopardize the state subsidy of the Eparchy of Mukachevo [4; 40: 98; 50: 28].

Stefan Pankovych tried to strengthen his position against Dobriansky by convening a "popular conference" between 8 and 10 January, 1871 . 
A report of "Svit" stated that 96 supporters of the bishop gathered in Uzhhorod [19]. According to the Hungarian journal "Ung", about 200 Greek Catholic and secular believers arrived at the seat of the Eparchy of Mukachevo to greet Bishop Stefan Pankovych on the occasion of his name day [66]. Members of the Rusin intellectuals gathered and wanted to make a statement against the A. Dobriansky's ecclesiastical autonomy program and expressed their adherence to the Esztergombased Hungarian Catholic Church. Yuriy Markosh (Gyorgy Markos), director of the Hungarian treasury in Uzhhorod, stated that Greek Catholics adhere to their ecclesiastical ceremony and faith, but not to ask for more in the field of ecclesiastical administration, than Roman Catholics deserve. This practically meant that it did not support the autonomy of the Greek Catholic Church, which fully complied with the will of the Hungarian political elite. Yu. Markosh stressed that the Rusins must distance themselves from the "Pan-Slavic" and "proRussian" aspirations of A. Dobriansky and his circle. At the meeting in Uzhhorod, Yu. Markosh's proposals were accepted, thus standing firmly in favour of the bishop [19; 40: 93; 66]. Then, Bishop Stefan Pankovych accepted the jurisdictional status of his eparchy under the authority of the Roman Catholic Church of Hungary at the Church Congress at Pest [28: 395-396; 74: 372]. He was the main Rusin proponent of the latinization and Hungarization of the Greek Catholic Church [5: 166; 24: 82; 72: 89, 190; 80: 216].

Bishop Stefan Pankovych was vigilant in ensuring that Russophilism in literature and linguistics did not spill over into political space [64:22]. An episcopal decree dated December 31,1870, called on the clergy to sever its relationship with the "Svit" because of its "dangerous tendencies" and to publish its official publications in the Hungarian-language newspaper, "Ung” [3: 25; 13: 94-98; 27: 290; 37: 19; 93: 74-76]. The bishop punished those priests who dared to criticize his person by relocation. Several of them emigrated to the Tsarist Empire (Emanuil Hrabar, Mykhaïl Molchan, Vladimir Terletskii) [3: 26; 28: 396; 59: 139; 64: 22-23].

It resonated greatly on January 21,1871 , when the society's management committee ousted the pro-Russian editor-in-chief of "Svit", Viktor Kymak, by a 21: 6 vote. At the same time, it was decided that the journal would appear in a new spirit, called "Novyi svit" [New Light]. According to the new editor-in-chief, Victor Gebei, this was necessary because "Svit" was neither religious nor civic in terms of compliance. The "Novyi svit" wanted to publish writings in vernacular instead of Greater Russian [3: 27; 5: 172; 25: 92; 64: 22-23]. The editor-in-chief made an attempt to declare the organ a political tabloid, but this plan failed in the absence 
of the required caution. Thus the last issue of the "Novyi svit" was published in December 1872. In this, V. Gebei announced his resignation as editor-in-chief [27: 291; 50: 30-31]. V. Padyak came to the conclusion that distribution of the new journal was not successful among the Rusin readership [26: 27]. Moreover, Stefan Pankovych considered the journal too Russophile in orientation [28: 396; 58: 444].

On June 20,1871, the former editor of "Svit", V. Kymak, launched a satirical journal entitled "Sova" [Owl]. Owing to the bishop's good connection with the Hungarian government Kymak did not dare to criticize Stefan Pankovych directly in his newspaper. Instead, caricatures of bishop suggested that he would make concessions to the Latin-ordained church that were already threatening the self-abandonment of Greek Catholics. The paper depicts A. Dobriansky as opposed to the bishop, usually as a defender of the Greek Catholic Church and Rusins [31; 35; 50: 35-37; 76:472]. After all, it was not surprising that "Sova" could only appear five times. The first three issues were published in Uzhhorod, the last two in the Minerva Printing House in Pest [79]. Stefan Pankovych transferred Kymak to Pécs, who instead chose emigration and accepted the position of headmaster in Odessa [56: 57; 64: 23].

On 28 September, 1871, there was a change of guard at the head of the St. Basil the Great Society. After about six years, at the renewal meeting held in Uzhhorod the course represented by Dobriansky and his circle ended. Member of Parliament, Oleksandr Nehrebetsky was elected the president of the society, and the manorial director, Yu. Markosh was elected the second president [3: 26; 13: 98; 27: 291; 36: 47-48]. With the renewal of the office, the St. Basil the Great Society was led by more loyal Rusin leaders who were unconditional followers of the bishop of Mukachevo. The general meeting took place in an intensified atmosphere. Then A. Dobriansky retreated to his estate in Csertész (Čertižné, today Slovakia) [13:110; 23: 163; 55: 37]. From that time on, I. Rakovsky did not take an active role in public life [75: 411].

The activities of Stefan Pankovych pushed his rivals into the background, but for a time the leadership of the St. Basil the Great Society was still significantly influenced by well-known Russophile writers and publicists such as Ivan Silvay,Anatolii Kralytskyi (Superior of St. Nicholas Basilian Monastery in Mukachevo), or levhenii Fentsyk. This wing rather became increasingly fragmented, and they were not able to play a direct role in the Rusin cultural affairs [23: 163; 38; 64: 24]. However, it did not mean that there were no people who aroused resentment against the bishop. In a heated debate, Stefan Pankovych taught I. Silvay: "If now we live under the rule of the Hungarians, then we should become Hungarians" [25: 102; 40: 97]. 
The bishop had several plans that also divided the Rusin prelacy. In his eparchy, instead of the Julian calendar, he would have introduced the Gregorian calendar used by Latin ceremonies [18: 96; 40:101; 72:190]. His intention of unifying the Byzantine rite with the Latin one increased tensions among Greek Catholic clergy. For instance, the idea provoked a fierce protest from the clergy of Maramorosh [65]. Another similarly controversial initiative of the bishop would have been to replace the Cyrillic alphabet with Latin letters. In December 1873, Ágoston Trefort, the Hungarian minister of education and religion called the Greek Catholic bishops of Prešov and Mukachevo to view their opinion on the possibility of script change. The possibility of introduction of Latin alphabet for Rusin language was opposed by Bishop losyf Gaganets of Prešov and by Mukachevo chapter [40: 99; 53: 201]. Stefan Pankovych was out of his seat when the local consistory expressed their opposition towards ministry's request [24: 65; 53: 201].

The raising of the calendar and alphabet reform touched on important elements of Rusin identity [53: 204]. Only the priests of Hajdúdorog and Zemplyn County supported the unification of the calendar. Eventually, Stefan Pankovych failed to accept either the transition to the Gregorian calendar or the eparchial use of the Latin alphabet with his clergy [40: 99; 63; 73: 66]. According to the pro-government "Pesti Naplo", the moderate Vicar Antal Csopey, was among the prelacy who counterbalanced the bishop's "anti-nationality" (meaning anti-Rusin) "calendar mania" and his intentions to introduce a calendar according to Latin ceremonies [47].

Stefan Pankovych proclaimed an eparchial synod on September 1, 1874 , where he probably wanted to raise issues of great significance before his priesthood. However, the 150 priests who appeared at the synod could only see their bishop at the funeral, as he died on August 29. Thus, the meeting chaired by Vicar Antal Csopey could not decide on important issues. Stefan Pankovych's death froze for a time the debates over the introduction of the Gregorian calendar and the Latin alphabet [40: 93-95; 44; 48; 53: 209; 54; 85].

The funeral of the bishop was held on September 2. It was celebrated by Chief Provost lulii Hadzhega and Vicar Antal Csopey. Many secular and ecclesiastical dignitaries appeared in Uzhhorod. Stefan Pankovych's body was laid to rest in the tomb of the Uzhhorod Cathedral [40: 101; 71; 84]. The work of the bishop was recognized and rewarded at the highest level by the Hungarian governments and Franz Joseph I. In 1869, Stefan Pankovych was awarded the middle cross of the knight of the Order of St. Stephen, and in the same year he was the real inner privy councillor of the ruler $[61,78]$. Two years later, Franz Joseph donated the first class of the Order of the Iron Crown to him [62]. 
The news of Stefan Pankovych's death was evaluated in different ways. The Russophile writer, Aleksander Pavlovych called him "the ancient enemy" of the Rusins [80: 217]. The other Russophile leader, I. Rakovsky firmly stated that during his bishopric the Rusin movement suffered a "fatal blow" [5: 201; 14: 388]. After the death of the bishop, the Hungarian political elite believed that it would be difficult to find a successor who would continue to take strong action against the Russophiles in Hungary [42]. In light of this, it is not surprising that the next bishop was a close relative of Stefan Pankovych, loann Pastelii Kovach.

As a son of a Rusin Greek Catholic priest, Stefan Pankovych began to pursue a typical career by following in his father's footsteps. During his student years, he adopted the norms of necessary to the dominant Hungarian culture. Working as a children's tutor of influential families, he tightened the relationship with the Hungarian aristocracy. As a bishop of the Rusin-dominated Eparchy of Mukachevo, he devoted a great deal of energy in developing of the eparchial infrastructure, building new churches, parish homes and schools. Bishop Stefan Pankovych tried to influence the clergy to adopt a pro-Hungarian orientation. He was highly critical of the A. Dobriansky-led Rusin movement. However, the influence of Russophiles still remained even after the bishop's death. We can also find nationally minded Rusin priests in the consistory who opposed to introduce the so-called "calendar reform" and script change. After the dominancy of the Russophile orientation declined, the "pro-Hungarian camp" became increasingly prominent in the Rusin intellectual circles. As a result of Stefan Pankovych's episcopate, the Mukachevo Eparchy no longer served as a bastion for Rusin national identity.

\section{REFERENCES}

1. Svit. (1870) Avtonomicheskoe sobranie [Autonomy Meeting]. 29th October (10th November). pp. 338-340.

2. Voloshin, A. (2002) Vibrani tvori. Uzhhorod: Zakarpattya. pp. 140-145.

3. Gadzhega, Yu. (1925) Istoriya "Obshchestva sv. Vasiliya Velikago" i rich'ko dnyu 60-litiya ot ego uchrezhdeniya [The History of St. Basil the Great Society and Speech to the Day of the 60th Anniversary of His Establishment]. Uzhhorod: Shkolnoy pomoshch.

4. Gomichkov, A.Yu. (1869) Tserkovnaya avtonmiya [Church Autonomy]. Svit. 23rd February (7th March). pp. 1-2.

5. Danilyuk, D. (1997) Istoriya Zakarpattya v biografiyakh i portretakh (z davnikh chasiv do pochatku XX st.) [History of Transcarpathia in Biographies and Portraits (from Ancient Times to the Early Twentieth Century)]. Uzhhorod: Patent.

6. The State Archives of Transcarpathian Oblast (DAZO). Fund 151. List 12. File 1316. Ark. 48. 
7. The State Archives of Transcarpathian Oblast (DAZO). Fund 151. List 12. File 1322. Ark. 11.

8. The State Archives of Transcarpathian Oblast (DAZO). Fund 151. List 12. File 1322. Ark. 25-26.

9. The State Archives of Transcarpathian Oblast (DAZO). Fund 151. List 12. File 2079. Ark. 1-5.

10. The State Archives of Transcarpathian Oblast (DAZO). Fund 151. List 12. File 2135. Ark. 1-19.

11. The State Archives of Transcarpathian Oblast (DAZO). Fund 151. List 12. File 2162. Ark. 1-3.

12. The State Archives of Transcarpathian Oblast (DAZO). Fund 151. List 12. File 2187. Ark. 1-2.

13. Dobosh, S. (1956) Adol'f Ivanovich Dobryanskiy: Ocherk zhizni i deyatel'nosti [Adolf Dobriansky: A Sketch of his Life and Activities]. Prešov: SVKL.

14. Nikitin, S.A. (ed.) (1975) Zarubezhnye slavyane i Rossiya. Dokumenty arkhiva M.F. Raevskogo. 40-80 gody XIX veka [Foreign Slavs and Russia. Documents from M.F. Rajewski's Archive. 1840-1880s]. Moscow: Nauka.

15. Svit. (1869) Kak imiem pisati? [How Do We Write?]. 17th (29th) August. pp. $1-2$.

16. Kashka, M.Yu.(2008) Etnopolitichniy rozvitok rusiniv-ukraïntsiv Zakarpattya (seredina XVIII st. - 1867 r.) [Ethnic and Political Development of UkrainianRusins in Transcarpathia (the mid-18th-1867)]. History Cand. Diss. Uzhhorod.

17. Kashka, M.Yu. (2011) Suspil'no-politichni protsesi v pivnichno-skhidnikh komitatakh Ugorshchini v 60-kh rokakh XIX st. [Socio-political Processes in the North-eastern Counties of Hungary during the 60's in the 19th Century]. Naukoviy visnik Uzhgorods'kogo universitetu. Seriya: Istoriya. 26. pp. 16-21.

18. Kondratovich, I.M. (1991) Istoriya Podkarpats'koï Rusi dlya naroda. [The History of Subcarpathian Rus for the People]. Facsimile edition. Uzhhorod: Patent.

19. Svit. (1871) Konferentsiya u mukachivskago katolicheskago episkopa i protest protiv 7 nashikh avtonomicheckikh predstaviteley [Conference at the Bishop of Mukachevo Eparchy and Protest against Our Seven Autonomous Representatives]. 7th (19th) January. pp. 4-5.

20.Svit. (1869) Kritika “Svita” [Critique of "Svit”]. 24th August (5th September).

21. Mayor, R.I. (2012) Parlaments'ka diyal'nist'A. Dobryans'kogo v ugors'komu seymi ta yogo borot'ba proti madyarizatsiï natsional'nikh menshin Ugorshchini v 1861-1868 rr. [A. Dobriansky's Parliamentary Activities in the Hungarian Sejm and His Struggle against Hungarisation of Minorities in Ugorshchina 1861-1868]. In: Stepankov, V.S. (ed.) Problemi istorii kraï Tsentral'noï ta Skhidnoï Evropi [Problems of History of Central and Eastern Europe]. Kamianets-Podilskyi: Kamianets-Podilskyi National University. pp. 120-140.

22. Mayor, R.I. (2013) Politika madyarizatsiï ta iï vpliv na rozvitok ukraïns'kogo natsional'nogo rukhu v Zakarpatti v seredini XIX - na pochatku XX st. [Magyarization Policy and Its Influence on the Development of the Ukrainian National Movement in Transcarpathia in the Middle of the Nineteenth and Early Twentieth Centuries]. Naukovi pratsi Kam'yanets'-Podil's'kogo natsional'nogo universitetu imeni Ivana Ogienka. Istorichni nauki. 23. pp. 324-343. 
23. Mayor, R.I. (2017) Russophilia in Transcarpathia in the Second Half of the 19th - early 20th Centuries: Origins, Development and Ideology. Rusin. 1(47). pp. 154-176. DOI: 10.17223/18572685/47/13

24. Meteor, U. (Silvay, I.A.) (1875) Polozhenie ugorskikh russkikh pod upravleniem Stefana Pankovicha, episkopa Mukachevskago [The Position of Ugric Rusins under Stephen Pankovich, Bishop of Mukachevo]. In: Golovatsky, Ya. et al. Slavyanskiy sbornik [Slavic Collection]. Vol. 1. St. Petersburg: Second Section of His Imperial Majesty's Own Chancellery. pp. 55-88.

25. Meteor, U. (Silvay, I.A.) (1938) Avtobiografiya [Autobiography]. Uzhhorod: Shkol'naya Pomoshch'.

26. Padyak, V. (2006) Uzhgorods'kiy tizhnevik "Novyy Svit" (1871-1872): Anotovana bibliografiya materialiv ta istorichniy naris [The Uzhgorod Weekly "Novyy Svit" (1871-1872): An Annotated Bibliography of Materials and a Historical Sketch]. Uzhhorod: V. Padyak.

27. Padyak, V. (2015) Tovariststvo sv. Vasiliya Velikogo v Uzhgorodi 150-richchya vid dnya zasnuvannya (1866-1902) [St. Basil the Great Society in Uzhhorod, 150th Anniversary from Its Foundation (1866-1902)]. In: Padyak, L.O. (ed.) Kalendar kraeznavchikh pam'yatnikh dat na 2016 rik [Calendar of Local History Anniversaries for 2016]. Uzhhorod: Vid-vo V. Padyaka. pp. 287-295.

28. Pap, S. (2003) Istoriya Zakarpattya [The History of Transcarpathia]. Vol. 3. Ivano-Frankivsk: Nova Zorya.

29. Misyatsoslov na 1867 god. (1866) Protokol Pervago obshchago sobraniya Obshchestva sv. Vasiliya Velikago proiskhodivshago v Uzhgorodi, 19 Sentyabrya (1. Okt.) 1866 goda [Protocol of the First General Meeting of St. Basil the Great Society, Held in Uzhhorod, 19th September (1st October) in the Year 1866]. Uzhhorod: Obshchestvo Sv. Vasiliya Velikago.

30. Svit. (1869) Protokol Chetvertago obshchago sobraniya Obshchetcva svyatago Vasiliya Velikago, proiskhodivshago v Ungvar, 18 (30) Sentyabrya $1869 \mathrm{~g}$. [Protocol of the Fourth General Meeting of St. Basil the Great Society, Held in Uzhhorod, 18th (30th) September in the Year 1869]. 26th October (7th November). pp. $1-2$.

31. Sova. (1871) Russkiy narod i intelligentsiya ego po syu storonu Karpat v 1871 godu [Rusin People and Its Intelligentsia on this Side of the Carpathians in 1871]. 20th June (2nd July). p. 8.

32. Pankovych, S. (1867) Rich', proiznesenna ego preosvyashchenstvom kir Stefanom Pankovichom bozhiim providiniem episkopom Mukachevskim [Speech Delivered By His Eminence Stefan Pankovych, the Divine Providence Bishop of Mukachevo]. Budini: [s.n.].

33. Sabov, E. (1893) Khristomatiya tserkovno-slavyanskikh i ugro-russkikh literaturnykh pamyatnikov, s pribavleniem ugro-russkikh narodnykh skazok na podlinnykh narnochiyakh [Christomacy of Church Slavonic and Ugro-Rusin Literary Monuments, With the Addition of Ugro-Rusin Folk Tales in Authentic Dialects]. Ungvar: Knigopechatnyy Fond Eparkhii Mukachevskoy.

34. Svitlik, N.M. (2017) Obshchestvo svyatogo Vasiliya Velikogo i knigotorgivlya v Avstro-Ugors'kiy imperiï v kintsi XIX st. [The Society of St. Basil 
the Great and the Book Trade in the Austro-Hungarian Empire in XIX Century]. Sotsium. Dokument. Komunikatsiya. Seriya: Istorichni nauki. 3. pp. 33-47.

35. Sova. (1871) Stseny na poprishchn literaturnom' russkikh po syu storonu Karpat v 1870-1871. godakh [Scenes from Rusin Literature on this Side of the Carpathians in the Years 1870-1871]. 7th (19th) July. p. 13.

36. Terletskiy, V. (1874) Ugorskaya Rus' i vozrozhdenie soznaniya narodnosti mezhdu russkimi $v$ Vengrii [Hungarian Rus and the Renaissance of National Consciousness among the Rusins of Hungary]. Kiev: Tip. S.T.Eremieva.

37. Svit. (1871) Ungvar, 13 yanvarya [Uzhhorod, 13th January]. 14th (26th) January. pp. 19-21.

38. Novyy Svit. (1871) Ungvar, 10-go (22-go) avgusta, 1871 [Uzhgorod, 10th (22th) August 1871]. 28.

39. St. Basil the Great Society. (1866) Ustav Obshchestva sv. Vasiliya Velikago [The Charters of St. Basil the Great Society]. Uzhhorod:Tipografiya Karla legera.

40. Fenich, V., Kichera, V. \& Shterr, D. (2018) Episkopi Mukachivs'koï grekokatolits'koï eparkhiï [The Bishops of the Greek Catholic Eparchy of Mukachevo]. In: Kichera, V., Fenich, V. \& Shterr, D. Gabsburz'ka tserkva: Mukachivs'ka grekokatolits'ka eparkhiya $v$ avstriys'ku dobu (1771-1918) [The Habsburg Church: The Greek Catholic Eparchy of Mukachevo in the Austrian era (1771-1918)]. Uzhgorod: Vidavnitstvo V. Padyaka. pp. 53-122.

41. Pesti Napló. (1875) A felsőbb közoktatás Magyarországon a múlt évben. Hittani intézetek. I. [Upper Secondary Education in Hungary Last Year. Theological Institutes. I.]. 23rd July. Morning edition.

42. Fövárosi Lapok. (1874) A munkácsi püspöki szék [The Episcopal Chair of Mukachevo]. 3rd September. p. 873.

43. A Hon. (1871) A szent falak mögül [From behind the Sacred Walls]. 9th April. Morning edition.

44. A Hon. (1875) A vidék [The Countryside]. 22nd April. Evening edition.

45. Máramaros. (1869) Anderkó vikárius nekrológja [Obituary of Vicar Anderko]. 16th June.

46. Balogh, M. (1909) A máramarosi görög szertartású orosz egyház és vicariatus történelme [The History of Greek Rite Ruthenian Church and Vicariate of Máramaros]. Ungvár: Unió Könyvnyomda Rt.

47. Pesti Napló. (1874) Bereghmegyéből, decz. 9. A munkácsi püspöki szék betöltése [From Bereg County, 9th December. The Occupation of the Episcopal Chair of Mukachevo]. 12th December. Evening edition.

48. Das Vaterland. (1874) Bischof Pankovics † [Bishop Pankovych †]. 2nd September. p. 3.

49. Borhalmi, G. (Bendász, I.) (1994) Kárpátalja első főiskolai jellegű intézménye [The First College of Higher Education in Subcarpathia]. Magyar Egyháztörténeti Vázlatok. 3-4. pp. 195-202.

50. Böör, Gy. (1943) A magyarországi ruszin időszaki sajtó a XIX. században [Periodical Journals of the Rusins in Hungary during the 19th century]. Kolozsvár: Ferenc József Tudományegyetem Történeti Intézete.

51. Deák, Á. (2008) From Habsburg Neo-Absolutism to the Compromise 1849-1867. New York: Columbia University Press. 
52. Fremden-Blatt. (1871) Der “Golos" [The “Voice”]. 24th November. p. 4.

53. Dwornik, K. (2020) First Subcarpathian Episode of Ruthenian Alphabet War in 1873-1874. Slavica Slovaca. 2(55). pp. 198-210.

54. Budapesti Közlöny. (1874) Halálozás [Mortality]. 3rd September. p. 1612.

55. Jasik, M. (2017) Adolf Dobriansky, významný predstavitel'Rusínov 19. storočia [Adolf Dobriansky, A Prominent Representative of the Rusins in the 19th Century]. Svidník: [s.n.].

56. Magocsi, P.R. (1978) The Shaping of a National Identity Subcarpathian Rus', 1848-1948. Cambridge, Mass. and London: Harvard University Press.

57. Magocsi, P.R. (1997) Adaptation Without Assimilation: The Genius of the Greco-Catholic Eparchy of Mukachevo. Logos: A Journal of Eastern Christian Studies. 1-4(38). pp. 269-281.

58. Magocsi, P.R. \& Pop, I. (2005) St. Basil the Great Society. In: Magocsi, P. R. \& Pop, I. (eds) Encyclopedia of Rusyn History and Culture. Toronto; Buffalo; London: University of Toronto Press. pp. 444-445.

59. Magocsi, P.R. (2015) With Their Backs to the Mountains: A History of Carpathian Rus' and Carpatho-Rusyns. Budapest; New York: Central European University Press.

60. Máramaros. (1874) Magyar Irodalmi Önképző Kör [Hungarian Literary Self-Education Circle]. 11th November. 89.

61. Hungarian National Archives (MNL OL). K 255. Pénzügyminisztériumi Levéltár [Ministry of Finance Archives]. 1869.

62. Hungarian National Archives (MNL OL). W 12. Minisztertanácsi jegyzőkönyvek [Protocols of the Cabinet of Ministers]. 8th March 1871.

63. Tages-Post. Linz. (1871) Magyarisirung auf kirchlichem Gebiete [Magyarization in the Ecclesiastical Field]. 2nd December. p. 2.

64. Mayer, M. (1977) Kárpátukrán (ruszin) politikai és társadalmi törekvések: 1860-1910 [Carpatho-Ukrainian (Ruthenian) Political and Social Aspirations: 1860-1910]. Budapest: Akadémiai Kiadó.

65. Máramaros. (1873) Naptárkérdés [The Issue of Calendar]. 5th November.

66. Ung. (1871) Nevezetes vallás-egyházi esemény Ungvárott. Január 10-én. [A Notable Religious and Church Event in Uzhhorod. On 10th January]. 14th January. p. 6.

67. Magyarország és a Nagyvilág. (1874) Pankovics István [Stefan Pankovych]. 13th September. pp. 349-350.

68. Katholikus Hetilap. (1873) Pankovics István munkácsi gör. kath. püspök [Stefan Pankovych, Greek Catholic Bishop of Mukachevo]. 28th August. p. 350. 69. Katholikus Néplap. (1868) Pankovics István munkácsi gör. kath. püspök [Stefan Pankovych, Greek Catholic Bishop of Mukachevo]. 5th March. pp. 73-74. 70. Máramaros. (1868) Pankovics István munkácsi Püspök úr Ő Méltóságának fogadtatása Huszton [The Welcome of His Excellency, Bishop Stefan Pankovych in Khust]. 16th September.

71. Budapesti Közlöny. (1874) Pankovics püspök temetése [The Funeral of Bishop Pankovych]. 10th September. pp. 1651-1652.

72. Pekar, A.B. (1992) The History of the Church in Carpathian Rus'. New York: Columbia University Press. 
73. Pirigyi, I. (1990) A magyarországi görög katolikusok története [The History of Greek Catholics of Hungary]. Vol. 2. Nyíregyháza: Görög Katolikus Hittudományi Főiskola.

74. Pop, I. (2005) Pankovych, Shtefan. In: Magocsi P.R. \& Pop I. (eds) Encyclopedia of Rusyn History and Culture. Toronto; Buffalo; London: University of Toronto Press. p. 372.

75. Pop, I. (2005) Rakovs’kyi, loann/Ivan. In: Magocsi P.R. \& Pop I. (eds) Encyclopedia of Rusyn History and Culture. Toronto; Buffalo; London: University of Toronto Press. p. 411.

76. Pop, I. (2005) Sova. In: Magocsi P.R. \& Pop I. (eds) Encyclopedia of Rusyn History and Culture. Toronto; Buffalo; London: University of Toronto Press. p. 472.

77. Budapesti Hirlap. (1883) Roskoványi nyitrai püspök [Roskoványi, Bishop of Nyitra]. 22nd December. p. 2.

78. Fövárosi Lapok. (1869) Rövid hírek [Short news]. 10th November. p. 1029.

79. Fövárosi Lapok. (1871) Rövid hírek [Short news]. 17th September. p. 979.

80. Rusinko, E. (2003) Straddling Borders: Literature and Identity in Subcarpathian Rus.' Toronto; Buffalo; London: University of Toronto Press.

81. S. Benedek,A. (2003) A gens fidelissima: A ruszinok [The Most Loyal People. The Rusins]. Budapest: Belváros-Lipótváros Ruszin Kisebbségi Önkormányzat.

82. Anon. (1865) Schematismus Venerabilis Cleri Graeci Ritus Catholicorum Dioecesis Munkacsiensis Pro Anno Domini 1865 [Schematism of the Venerable Greek Rite Catholic Clergy of Mukachevo Diocese of the Year of 1865]. Unghvarini: Typis Caroli Jäger.

83. Szabad, Gy. (1979) Az önkényuralom kora (1849-1867) [The Age of Despotism (1849-1867)]. In: Kovács, E. \& Katus, L. Magyarország története 1848-1890 [History of Hungary 1848-1890]. Vol. 1. Budapest: Akadémiai Kiadó. pp. $435-768$.

84. Neuigkeits Welt-Blatt. (1874) Ueber das Leichenbegängniß des Bischofs Pankovics [About the Funeral of Bishop Pankovics]. 10th September. p. 5.

85. Salzburger Kirchenblatt. (1874) Ungarn [Hungary]. 3rd September. p. 284.

86. Budapesti Közlöny. (1867) Ungvár, martius 23án [Uzhhorod, on 23rd March]. 16th April. p. 318.

87. Pesti Napló. (1867) Ungvárott, jun. 3. [In Uzhhorod, 3rd June]. 20nd June. 88. Pesti Napló. (1867) Ungvár, oct. 18. [Uzhhorod,18th October]. 29th October. 89. Pesti Napló. (1869) Ungvár, october 2. [Uzhhorod, 2nd October]. 5th October.

90. Máramaros. (1869) Vallási mozgalom Szigeten [Religious Movement in Shiget]. 30th June.

91. Véghseő, T. (2014) A görögkatolikus magyarok mozgalma a kezdetektöl 1905-ig [The Movement of Greek Catholic Hungarians from the Beginning until 1905]. In: Véghseő, T. \& Katkó, M.Á. Források a magyar görögkatolikusok történetéhez. 1778-1905 [Sources to the History of Hungarian Greek Catholics. 1778-1905]. Vol. 1. Nyíregyháza: Szent Atanáz Görögkatolikus Hittudományi Föiskola. pp. 31-47.

92. Véghseő, T. \& Katkó, M. Á. (2014) Források a magyar görögkatolikusok történetéhez. 1778-1905 [Sources to the History of Hungarian Greek Catholics. 
1778-1905]. Vol. 1. Nyíregyháza: Szent Atanáz Görögkatolikus Hittudományi Főiskola.

93. Žeguc, I. (1965) Die nationalpolitischen Bestrebungen der Karpato-Ruthenen 1848-1914 [The National Political Aspirations of the Carpato-Rusins in 1848-1914]. Wiesbaden: Harrassowitz.

Ferenc Molnár - Ferenc Rákóczi II Transcarpathian Hungarian College of Higher Education (Ukraine).

Ференц Молнар - доктор философии, доцент кафедры истории и общественных дисциплин Закарпатского венгерского института им. Ференца Ракоци II (Украина).

E-mail:molnarkmf@gmail.com 